\title{
Impacts of Religious and Pilgrimage Tourism in Rural Areas: The Case of Iran
}

\author{
Mehdi Pourtaheri ${ }^{1}$, Khalil Rahmani ${ }^{2}$ \& Hassan Ahmadi $^{1}$ \\ ${ }^{1}$ Assistant Professor, Department of Geography, Tarbiat Modares University, Tehran, Iran \\ ${ }^{2}$ Graduate Student in Geography and Rural Planning, Tarbiat Modares University, Tehran, Iran \\ Correspondence: Mehdi Pourtaheri, Assistant Professor, Department of Geography, Tarbiat Modares University, \\ Jalale-Ale-Ahmad Express Way, Tehran, Iran. E-mail: Mahdit@modares.ac.ir
}

Received: July 24, $2012 \quad$ Accepted: August 12, 2012 Online Published: August 17, 2012

doi:10.5539/jgg.v4n3p122 URL: http://dx.doi.org/10.5539/jgg.v4n3p122

\begin{abstract}
Rural tourism has speedily developed and become an engine for economic development and plays a great role towards socio-economic changes in rural areas. However, its impact is controversial and not always obvious. To examine these issues, this research presents an empirical analysis of pilgrimage and religious tourism and the impacts of these types of travel in rural areas in Iran. The paper provides examples of these impacts and transformations in the three rural centers as Tourism Model Villages (TMVs). A qualitative method and survey questionnaire was distributed to 300 households in the study area and the data analyzed by use of One-sample T-test, Kruskal-Wallis and tukey test in SPSS software. In this regards the social, physical and economic impacts on the transformation of rural households are discussed. The results revealed that pilgrims and religious tourists are strongly influenced in rural areas, but the social aspect of pilgrimage and religious tourism had the largest impacts on rural households. And also the results indicated that the villages related to "Religious tourism", have registered statistically significant higher impacts of those villages related to "Pilgrimage tourism".
\end{abstract}

Keywords: pilgrimage, religious tourism, rural development, rural tourism, Iran

\section{Introduction}

Tourism activity in rural areas has remarkably increased since the $70 \mathrm{~s}$ in all developed countries. Along with the development of rural tourism worldwide, rural tourism concept has many Interpretations. Conceptually, rural tourism may be regarded as tourism in the countryside that embraces the rural environment as pivotal to the product offered (Clarke, Denman, Hickman, \& Slovak, 2001). In 1996, Pedford further broaden the concept of rural tourism to include living history of countryside such as rural custom and folklore, local and family traditions, values, beliefs, and common heritage ( $\mathrm{Su}, 2011$; MacDonald \& Jollifee, 2003). A lot of studies are applied to examine the processes of growth and development of rural settlements affected by tourism (Nepal, 2007).

Tourism has played a key role in the development of some rural zones that were economically and socially depressed (Perales, 2002; Deller, 2009). Peripheral and rural areas have frequently looked to it as a tool for promoting local jobs and a pathway to rural regeneration and to the diversification and restructuring of rural economy (Fleischer \& Felsenstein, 2000; Panyik, Costa, \& Rátzl, 2011; Park, 2009; Cawley \& Gillmor, 2007). Tourism is an option for enhancing rural lifestyles and for inducing positive changes in the distribution of income in underprivileged regions.

Tourism helps to energize the rural economy and, in particular, plays an important role in creating a value -added commercial channel for local produce (Liu, 2006; 1993; Augustin, 1998). Fons, Fierro and Patino (2011) claim that less investment is needed for the rural area than for mass tourism, either because of smaller size or because of lower prices, so the profit is more immediate and the risk is smaller too. Fleischer and Tchetchik (2005) elaborate further and claim that rural tourism have been developed in rural areas as an alternative to agriculture development. The pivotal position of tourism arises because many rural resources have potentially strong linkages with it (Saxena \& Ilbery, 2007). The convergence of the host community and tourist activities is mediated chiefly by local resources (Saxena \& Ilbery, 2010). 
Tourism has long been considered as a potential means for socio-economic development and regeneration of rural areas, in particular those affected by the decline of traditional agrarian activities. Peripheral rural areas are also considered to be repositories of older ways of life and cultures that respond to the postmodern tourists' quest for authenticity. Thus, the encouragement for rural tourism has become a common policy both in developed countries (Iorio \& Corsale, 2010; Sharpley, 2002).Tourism is an option for enhancing rural lifestyles and for inducing positive changes in the distribution of income in underprivileged regions. Tourism has become the priority tool of rural planning orthodoxy and a lever for economic and social development. Meanwhile, rural tourism has often been identified as a vehicle for safeguarding the integrity of the countryside resource, enhancing the rural economy and maintaining rural ways of life (Garrod, Wornell, \& Youell, 2006).

In many countries, rural tourism has enjoyed substantial encouragement, support and, in some cases, financial assistance from both the public and private sectors. Over the last three decades, many rural economies have suffered a severe downturn, with falling employment and income levels in traditional agrarian industries contributing to a vicious circle of economic decline and socio-economic problems. In particular, per capita rural incomes have fallen well below national averages, whilst the loss of public services, high unemployment levels and the consequential out-migration of younger, better educated members of rural communities have collectively endangered the fabric and structure of rural areas.

As a result, not only has tourism been embraced as a potential means of reversing this decline but also, given the intimate relationship between the socio-economic health of rural areas in general and the prosperity of the farming community in particular, it has become an integral element of sustainable rural development policy.

More specifically, the development of rural tourism offers potential solutions to many of the problems facing rural areas. These may be summarized to economic growth including, diversification and stabilization through employment creation, opportunities for income growth and creation of new markets for products, socio-cultural development through re-population of rural areas, the maintenance and improvement of public services and increased opportunities for social contacts and also environment development by protection of both the natural and built environment (Sharpley, 2002).

A review of previous literature on rural tourism motivation reveals that people travel because they are "pushed" into travelling by internal reasons or factors, or because they are "pulled" by destination attributes (Devesa, Laguna, \& Palacios, 2009). Generally with the passage of time their travel turned to several new dimensions-travel as an adventure, travel as hobby, for relaxation, to enjoy natural beauty, as a pilgrimage, to acquire knowledge on historical aspects and archaeological sites. Travel to rural centers sometimes is associated with adventure and sometimes for religious purpose by visiting pilgrimages or by taking holy dip. Practice emphasizes that religion has played an important role for the development of many activity fields and also for human development. Many researches deal with religious phenomenon and analyze it as a determinant factor, a cultural element, and an important component of economic and social activities.

Religious attraction is an important element of the rural tourism services consumer's motivation. On domestic front Pilgrim Tourism can be very helpful for regional development, employment generation, and can enroot again the cultural values. Religious tourism generates revenue in a way as no other kind of tourism does (Karar, 2010). Religiously motivated tourism is probably as old as religion itself and is consequently the oldest type of tourism.

In many Muslim nations, Islam is the foundation of society and order of Islamic law principles supports tourism policy, development objectives, and management. Shia Pilgrimage is also a popular feature of Islam with a long history. The tombs of the Imams and their immediate descendants and close associates (known as Imamzadeh, a name also given to their shrines) evolved into places of Shia pilgrimage as Islam spread across Iran, Iraq, Saudi Arabia, and Syria.

Iran's tourism potentialities have been known as one of the important sources for rural development particularly due to the presence of many religious touristy places in rural areas. Rural communities in Iran are facing serious problems including poverty, illiteracy, depopulation and unemployment. These problems have caused the stagnation of the rural economy and the degradation of the quality of rural life.

In recent years in Iran attention to rural development through tourism attractions has been considered. Since 2005, the Iran's Government has been playing a leading role in the development of rural tourism. The Tourism Model Villages (TMVs) is main project that have focused on rural tourism development in sample villages to encourage of economic, social and environment development revolving around the development of local resources. In this context, it seems pilgrimage and religious tourism offers opportunities for generating and diversifying revenues for rural households in Iran. Thus the major objective of the study is to assess the effects of religious and 
pilgrimage tourism on economic, social and physical dimensions of Oraman-e-Takht, Hajyj and Najjar as Tourism Model Villages (TMVs) in the Oraman Region (see Figure 1).

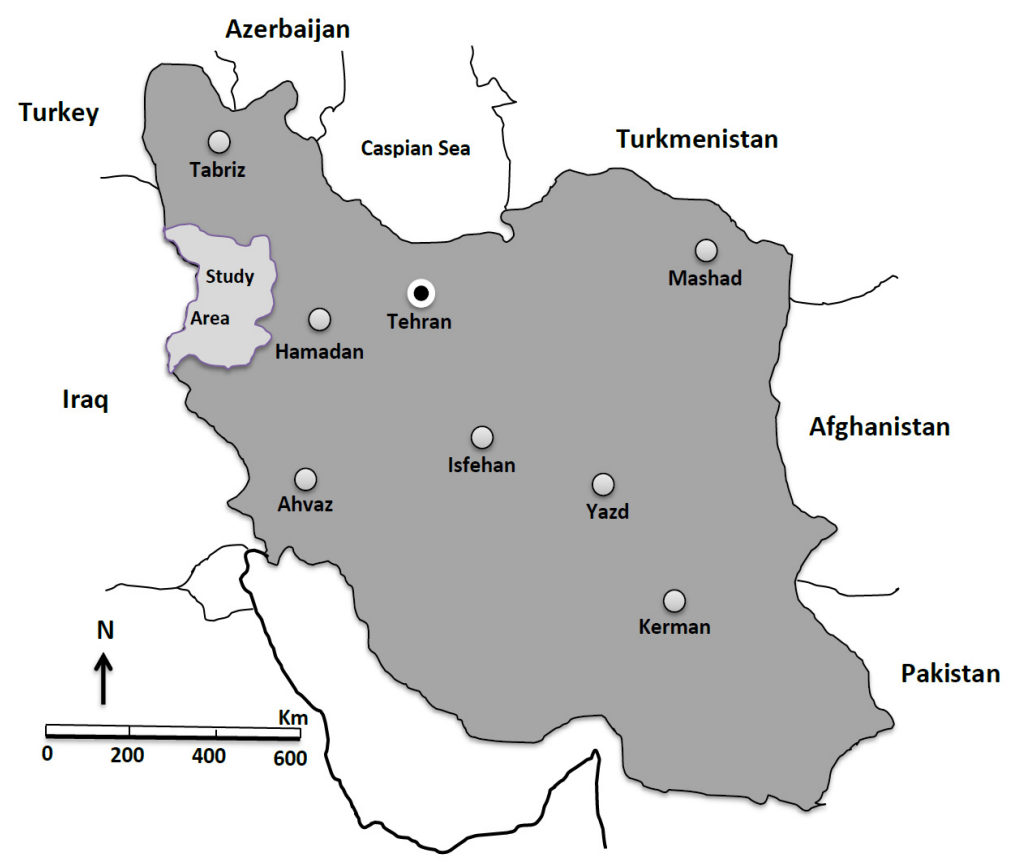

Figure 1. Location of study area, Oraman Region, Iran

\section{Pilgrimage and Religious Tourism in Rural Areas}

The debate on the importance of, and distinction between, tourism as a ritual and as a form of spirituality has not been conclusive (UNWTO, 2011). But, with an increasing differentiation of pilgrimage, religious tourism and usual tourism, and the difference between the wishes of people to search for a new meaning to their everyday life, all the shifts described show that the study of pilgrimage and religious tourism are being modified in the twenty-first century (Collins-Kreiner, 2010). Libeson, Muraleedharan (2008) and Rathod (2009) depicted different impacts of pilgrimage and religious tourism and elaborated on the causes of their success for rural residents in India. The concept of pilgrimage towards a certain site, as an act of will or religious obligation is known from ancient times (Josan, 2009). It has been argued that overall, pilgrims want to feel near to God and to find the calm and solace ensuing from this proximity. Pilgrimage is one of the oldest forms of tourism and is an integral component of the tourist industry (Rotherham, 2007). A pilgrimage has been defined as a journey resulting from religious causes. Generally, there is a gap in the difference between pilgrimage and tourism from the religious perspective. The issue of pilgrim versus tourist must be examined on two levels: first, from the perspective of the religious organizations and the travelers themselves and from the viewpoint of the industry (Collins-Kreiner, 2010). In the first approach pilgrims are not tourists because they travel for spiritual reasons and in the second approach pilgrims are tourists and should be treated as such.

The spiritual dimension of contemporary tourism has long been the focus of academic study, two principal analytical perspectives being in evidence. On the one hand, significant attention has been paid to so-called religious tourism. This type of tourist is partly or wholly motivated by religion, but travel is "connected with holiday-making or with journeys undertaken for social, cultural or philosophical reasons" (Fischer, 2003). Reflecting the importance of pilgrimage as one of the oldest forms of tourism, much of this literature is typically located within the now familiar 'tourist as pilgrim' framework, exploring the similarities and distinctions between contemporary religious tourism and pilgrimage (Sharpley \& Jepson, 2010). Alecu (2010) demarcates several specific elements of pilgrimage and religious tourism as a form of travel that are relevant to our research. He also adjusted to the motivation of travelling from pilgrimage to tourism in the five sections. This approach is presented in Figure 2. 


\begin{tabular}{|c|c|c|c|c|}
\hline \multicolumn{2}{|l|}{ Pilgrimage } & \multicolumn{2}{|c|}{ Religious tourism } & Tourism \\
\hline I & II & III & IV & V \\
\hline $\begin{array}{l}\text { belief is the } \\
\text { fundamental } \\
\text { motivation } \\
\text { and } \\
\text { we are } \\
\text { dealing with a } \\
\text { pious pilgrim }\end{array}$ & $\begin{array}{l}\text { belief motivation } \\
\text { is stronger than } \\
\text { the tourism } \\
\text { motivation and } \\
\text { thus we are } \\
\text { dealing with the } \\
\text { majority } \\
\text { of pilgrims }\end{array}$ & $\begin{array}{l}\text { travelling has } \\
\text { multiple motivations } \\
\text { either equally } \\
\text { powerful or } \\
\text { complementary; the } \\
\text { tourists shows the } \\
\text { need for culture and } \\
\text { also for } \\
\text { accumulating new } \\
\text { experiences }\end{array}$ & $\begin{array}{l}\text { cultural needs are } \\
\text { interweaved with } \\
\text { the needs for } \\
\text { entertainment, and } \\
\text { visiting religious } \\
\text { sites is but a } \\
\text { source of } \\
\text { knowledge and } \\
\text { active relaxation }\end{array}$ & $\begin{array}{l}\text { we are dealing } \\
\text { with the usual } \\
\text { tourism, where the } \\
\text { motivation for } \\
\text { relaxation and } \\
\text { entertainment is } \\
\text { predominant }\end{array}$ \\
\hline
\end{tabular}

\begin{tabular}{|l|l|l|}
\hline Belief & culture & Entertainment \\
\hline
\end{tabular}

Figure 2. Motivation for tourism and pilgrimage (Source: I. C. Alecu, 2010, p. 61)

Thus, the rural is not only as a physical place for relaxation and entertainment, but as a place with spiritual resonances, with connotations of romantic simplicity (Kneafsey, 2001).

\section{Methodology}

This investigation was designed to further understand the impacts of pilgrimage and religious tourism in the Iran countryside. Field research was undertaken over 2 weeks and the data were collected from rural households of three pilgrimage and religious tourism villages on March 2011 and 300 valid responses were obtained by applying systematic random sampling technique. The sample was in terms of sex, with predominance of men (80\%); a mean age around 40 year. The scale was developed with 15 items on a 5-point Likert-type scale from 1 (very low) to 5 (very high). Questions were closed and mainly focused on the three dimensions:

- Economic dimension, including the income increase, job creation, create commercial and retail centers, handicraft development and increase of land price.

- Social dimension, including the friendly communication with nearby villages, increase of sense of security, reduction of social conflicts in the village, reduction of migration, increase of social interaction with pilgrims and tourists.

- Physical dimension, including the access to services, enhance the quality of housing, improvement of rural transportation system, increase of quality of services and promote of health field.

The selection of these items was based on previous researches and literature review. Reliability based on Cronbach's alpha coefficient for the final scale resulted in a robust value (0.8). Data from questionnaires analyzed by use of One-sample T-test, Kruskal-Wallis and Tukey test in SPSS software. The One sample t-test procedure tests whether the mean of a single variable (mean value) differs from a specified constant (test value). And also the Kruskal-Wallis and Tukey test compares two or more groups of cases (villages) on one variable (each item) for several independent Samples. This test indicates if all samples are from populations with the same characteristics. In fact, The Kruskal-Wallis and Tukey test are the nonparametric analog of one-way analysis of variance and detects differences in distribution location. The output shows the number of valid cases and the mean rank of the variable in each group in the Ranks table.

\section{Study Area}

Surely one of the most important religious and pilgrimage tourism centers in Tourism Sample Villages (TSV) of Iran is located in the Oraman region and within the historical and religious villages i.e. Oraman-e-Takht, Hajyj and Najjar.

Oraman-e-Takht is a village in Division with the same name that located Sarvabad city in Kurdistan province. Specific architectural of village, as well as special ceremonies and customs and the existence of old mosque and tomb of Pir-e Shaliar indicate its importance. There are 600 households in this village that 3000 people are living there. One of the ancient ceremonies and Celebrations of the Kurd people in Oraman-e-Takht region is Pir-e 
Shaliar wedding ceremony that rooted in their ancient mythological beliefs and ancient religion. In the Oraman-e-thakht travelling has multiple motivations and the tourists show the need for culture and also for accumulating new experiences. And also Hajyj village with 163 households and over than 603 population that living there located in Kermanshah Province. In this wonderful and stepped village located shrine of Seyed Obaidullah. In the Hajij village belief motivation is stronger than the tourism motivation for travelling thus we are dealing with the majority of pilgrims. Also, the Najjar village with 65 households and 390 population located in Kermanshah Province. Shrine's Shams-ol-Alarfyn Sheikh Mohammed's Najjar and his son located in this village. In the Najjar village belief is the fundamental motivation for travelling thus we are dealing with a pious pilgrims. This place for each village is presented in Figure 3.

\begin{tabular}{|l|c|c|}
\hline Pilgrimage & Religious tourism & Tourism \\
\hline
\end{tabular}

\begin{tabular}{r|c|c|r|r|l} 
I & II & III & IV & V & \\
\hline Najjar village & Hajij village & $\begin{array}{c}\text { Oraman-e-thakht } \\
\text { village }\end{array}$ & & &
\end{tabular}

\begin{tabular}{|l|l|l|}
\hline Belief & culture & Entertainment \\
\hline
\end{tabular}

Figure 3. The place of each village from pilgrimage to religious tourism

The hundreds of the pilgrims and tourists come to these villages from the different province and districts. So it seems during the last one decade these villages have witnessed remarkable changes in economic, social and physical dimensions.

\section{Findings}

The mean values and standard deviations of the 15 variables are presented in Table 1 . The descriptive statistics of the variables revealed that the majority of respondents believe pilgrimage and religious tourism have influenced in their living conditions. The Increase of social interaction with pilgrims and tourists had been very high, as it is shown by the mean values (4.90) and increase of land price had been low by the mean values (3.47). Between $79 \%-90 \%$ of respondents admit that their social living condition has highly improved through presence of pilgrims and religious tourists. With relate to the impacts of pilgrimage and religious tourism on social living condition of families, we get similar results as in the case of physical and economic living conditions.

Table 1. Mean values and standard deviations of the impacts indicators

\begin{tabular}{lccc}
\hline \multicolumn{1}{c}{ Name of the variable } & $\mathrm{N}$ & Mean & Mean Rank \\
\hline S1= Friendly communication with nearby villages & 300 & 4.7933 & 10.70 \\
S2 = Increase of sense of security & 300 & 4.8500 & 11.09 \\
S3 = Reduction of social conflicts in the village & 300 & 4.5000 & 8.78 \\
S4= Reduction of migration , particularly for young people & 300 & 4.8467 & 11.07 \\
S5 = Increase of social interaction with pilgrims and tourists & 300 & 4.9000 & 11.40 \\
P1= Access to services (educational, administrative , etc $)$ & 300 & 4.5767 & 9.30 \\
P2= Enhance the quality of housing & 300 & 4.4467 & 8.45 \\
P3= Improvement of rural transportation system & 300 & 4.5667 & 9.21 \\
P4= Increase of quality of services & 300 & 4.4500 & 8.45 \\
P5= Promote of health fields such as waste and sewage disposal & 300 & 4.5367 & 9.02 \\
E1= Income increase & 300 & 3.6433 & 4.25 \\
E2= Job creation & 300 & 3.9000 & 5.49 \\
E3 = Create commercial and retail centers & 300 & 3.8500 & 5.34 \\
E4= Handicraft development & 300 & 3.5967 & 3.98 \\
E5 = Increase of land price & 300 & 3.4767 & 3.47 \\
\hline
\end{tabular}


There is significant difference between test value and mean value in all of the aspects, because P-Value of t-test is less than 0.05 by use of One-sample T-test (Table 2).

Table 2. Comparison of development dimensions by One-sample T-test

\begin{tabular}{lccccc}
\hline & \multicolumn{5}{c}{ Test Value $=15$} \\
\cline { 2 - 6 } \multicolumn{1}{c}{ Aspects } & $\mathrm{t}$ & $\mathrm{df}$ & Sig. & Mean value & Mean Difference \\
\hline Social & 184.0 & 299 & .000 & 23.9 & 8.89000 \\
Physical & 107.3 & 299 & .000 & 22.5 & 7.57667 \\
Economic & 46.49 & 299 & .000 & 18.4 & 3.46667 \\
\hline
\end{tabular}

Although the living condition is significantly different at all levels, but the highest levels of development has occurred in social and physical aspects. Thus, pilgrimage and religious tourism has the greatest impacts on improving the social and physical capacities of rural areas. In order to test the different between villages in the average of economic, social and physical impacts Kruskal-Wallis and Tukey test were used. The results of the Kruskal-Wallis test in social, physical and economic aspects show that the total of items in three villages (with the exception of Increase of sense of security and reduction of migration, particularly for young people and also create commercial and retail centers) are not the same (because its significance value is less than 0.05). The output of the Tukey Test also shows there is significance difference between villages in mean value of social, physical and economic aspects. The largest social impact has occurred in Oraman-e-takht village. The same result has occurred in physical and economic aspects in three villages. These findings are thematically similar to those reported in social aspects. Means for villages in three homogeneous subsets are displayed in Table 3.

Table 3. Mean values of social impacts in homogeneous subsets

\begin{tabular}{|c|c|c|c|c|c|c|c|c|c|c|}
\hline \multirow[t]{2}{*}{ village } & \multirow[t]{2}{*}{$\mathrm{N}$} & \multicolumn{3}{|c|}{$\begin{array}{l}\text { Subset for alpha }=0.05 \\
\text { Social effects }\end{array}$} & \multicolumn{3}{|c|}{$\begin{array}{c}\text { Subset for alpha }=0.05 \\
\text { Physical effects }\end{array}$} & \multicolumn{3}{|c|}{$\begin{array}{l}\text { Subset for alpha }=0.05 \\
\text { Economic effects }\end{array}$} \\
\hline & & 1 & 2 & 3 & 1 & 2 & 3 & 1 & 2 & 3 \\
\hline Najjar & 67 & 23.3 & & & 21.5 & & & 17.4 & & \\
\hline Hajij & 98 & & 23.8 & & & 22.4 & & & 18.2 & \\
\hline Oraman-e-takht & 135 & & & 24.2 & & & 23.2 & & & 19.0 \\
\hline Sig. & & 1.00 & 1.00 & 1.00 & 1.00 & 1.00 & 1.00 & 1.00 & 1.00 & 1.00 \\
\hline
\end{tabular}

So, the living condition is significantly different at the more items in three villages but the highest and lowest level of development in order has occurred in Oraman-e-takht and Najjar villages. Thus, it seems religious tourism has more impacts than pilgrimage tourism on improving the social, physical and economic aspects of rural households.

\section{Discussion and Conclusions}

In the recent decade, the government of Iran, has play a decisive role in developing rural tourism as a priority tool to enhance quality of life and produce positive change in poverty-stricken rural areas by project of Tourism Model Villages (TMVs). The development of rural tourism in the model villages is not only providing a supplementary income and new employment opportunities to local communities but also providing an opportunity to revitalize local crafts, Improvement of rural transportation system, Increase of quantity and quality of services, Create commercial and retail centers, Reduction of migration, particularly for young people and, etc. The analysis undertaken here appears to support recent findings reported in the academic milieu with regard to the importance of pilgrimage and religious tourism in rural development, but further provides evidence on the consequences of pilgrimage and religious tourism on rural households.

This paper reported on the impacts of economic, social and physical of the Tourism Model Villages (TMVs) project for rural pilgrimage and religious tourism promotion in the context of local-level in Iran. In This research a quantitative-method approach was applied to explore and compare the viewpoints of the respondents in Oraman-e-Takht, Hajyj and Najjar as Tourism Model Villages (TMVs). The principal objective of the study was to derive key economic, social and physical impacts of pilgrimage and religious tourism in the rural areas and also understanding of how this kind of tourism have enhanced the social, physical and economic potential of families living in the Iranian rural areas. Oraman-e-Takht, Hajyj and Najjar attract both internal and external 
tourists round the year. Several small commercial and retail center with their marketable commodities to fulfill the need and requirements of the pilgrims and religious tourists. A number of people and households are involved, directly or indirectly, in the sphere of pilgrim and religious tourism activities in these three villages. There are two main inferences to be drawn from the one-sample t-test, Kruskal-Wallis and Tukey test analysis performed to detect statistically difference significant between three villages and 15 items for impacts assessment.

First, perhaps the most striking finding of this research is the corroboration of one of the major inferences drawn from the qualitative method concerning the importance of pilgrimage and religious tourism in rural development by the statistical results. The results of the one-sample t-test showed that pilgrims and religious tourists are strongly influenced in rural areas, but the social aspect of pilgrimage and religious tourism had the largest impacts on rural households. Mean value of social impacts indicated (mean value $=4.77$ ), which included Increase of social interaction with pilgrims and tourists (4.90), Reduction of migration, particularly for young people (4.84), Increase of sense of security (4.84), Friendly communication with nearby villages (4.79), and Reduction of social conflicts in the village (4.50). This type of rural tourism provide not only social profits, but also physical (mean value $=4.51)$ and economic benefits (mean value $=3.69)$, helping to enhance the quality of housing, improvement of rural transportation system, access to services (educational, administrative, etc), increase of quality of services, promote of health fields such as waste and sewage disposal, income increase, job creation, create commercial and retail centers, handicraft development and increase of land price. Thus confirming existent literature, and adding new information at the same time, it has been found that social impacts are superior to economic impacts from view point of people who get involved in pilgrimage and religious tourism.

Second, the profiles of these three villages showed significant differences in social, physical and economic aspects. The results of the Kruskal-Wallis and Tukey test showed that Oraman-e-Takht village that we have named as a village dependent on Religious tourism have more impacts upon rural households than Hajyj and Najjar as villages dependent on pilgrimage tourism. So, the villages related to "Religious tourism", have registered statistically significant higher impacts of those villages related to "Pilgrimage tourism". Perhaps the most striking cause of this dominance is multiple motivations among religious tourists. In this kind of tourism the tourists shows the need for culture and also for accumulating new experiences while in pilgrimage tourism, belief is the fundamental motivation of travel and it is profoundly religious. The identification of these attributes, which are able to determine difference between Tourism Model Villages (TMVs), is very useful in the direction of configuration and planning for rural tourism development.

Lastly, although rural tourism in Iran is still at an introductory stage but, Iran's experience in development of pilgrimage and religious tourism in rural areas as an effective tool to revitalizing rural communities could be a model for rural development. As such, it is important that the pilgrimage and religious tourism are not viewed as a panacea for the complex problems of Iranian rural areas but, rather as one form of social and economic relationship that could strengthen the local capabilities through developing linkages to rural households and tourists. It is hoped that this study will help generate interest for further studies in Iran's rural tourism to enrich the literature in this academic field.

\section{Acknowledgments}

The authors would like to thank Dr. Abdolreza Eftekhari for his precious comments. And also special thanks to the families interviewed, who shared with authors their kindness and great patience. The preparation of this article was supported by the Tarbiat Modares University.

\section{References}

Alecu, I. C. (2010). Epistemological aspects of religious tourism in rural areas. International Journal of Business, Management and Social Sciences, 2(3), 59-65.

Augustin, M. (1998). National strategies for rural tourism and sustainability. The Experience Journal of Sustainable Tourism, 4(3), 3-33.

Cawley, M., \& Gillmor, D. A. (2007). Integrated rural tourism: Concepts and Practice. Annals of Tourism Research, 35(2), 316-337. http://dx.doi.org/10.1016/j.annals.2007.07.011

Clarke, J., Denman, R., Hickman. G., \& Slovak, J. (2001). Rural tourism in Roznava Okres: a Slovak case study. Tourism Management, 22, 193-202. http://dx.doi.org/10.1016/S0261-5177(00)00038-8

Collins-Kreiner, N. (2010). The geography of pilgrimage and tourism: Transformations and implications for applied geography. Applied Geography, 30, 153-164. http://dx.doi.org/10.1016/j.apgeog.2009.02.001 
Deller, S. (2009). Rural Poverty, Tourism and Spatial Heterogeneity. Annals of Tourism Research, 37(1), 180-205. http://dx.doi.org/10.1016/j.annals.2009.09.001

Devesa, M., Laguna, M., \& Palacios, A. (2010). The role of motivation in visitor satisfaction: Empirical evidence in rural tourism. Tourism http://dx.doi.org/10.1016/j.tourman.2009.06.006

Fischer, C. B. (2003). Monument or Mall? Pilgrimage and Tourism in Indonesia. Starr King School for the Minestry, American Academy of Religion's annual meeting, Atlanta, 1-8.

Fleischer, A., \& Felsenstein, D. (2000). Support for rural tourism: Does it Make a Difference? Annals of Tourism Research, 27(4), 1007-1024. http://dx.doi.org/10.1016/S0160-7383(99)00126-7

Fleischer, A., \& Tchetchik, A. (2005). Does rural tourism benefit from agriculture? Tourism Management, 26, 493-501. http://dx.doi.org/10.1016/j.tourman.2003.10.003

Fons, M. V. C., Fierro, J. A. M., \& Patino, M. G. Y. (2011). Rural tourism: A sustainable alternative. Applied Energy, 88, 551-557. http://dx.doi.org/10.1016/j.apenergy.2010.08.031

Garrod, B., Wornell, R., \& Youell, R. (2006). Re-conceptualising rural resources as countryside capital: The case of rural tourism. Journal of Rural Studies, 22, 117-128. http://dx.doi.org/10.1016/j.jrurstud.2005.08.001

Iorio, M., \& Corsale, A. (2010). Rural tourism and livelihood strategies in Romania. Journal of Rural Studies, 26 , 152-162. http://dx.doi.org/10.1016/j.jrurstud.2009.10.006

Josan, J. (2009). Pilgrimage - A rudimentary from of modern tourism. GeoJournal of Tourism and Geosites ,Year II, 4(2), 160-168.

Karar, A. (2010). Impact of Pilgrim Tourism at Haridwar. Anthropologist, 12(2), 99-105.

Kneafsey, M. (2001). Rural Cultural Economy: Tourism and Social Relations. Annals of Tourism Research, 28(3), 762-783. http://dx.doi.org/10.1016/S0160-7383(00)00077-3

Libeson, K. B., \& Muraleedharan, K. P. (2008). Economic benefits of pilgrimage tourism: A case study of Sabarimala pilgrimage with special reference to Pandalam rural locality in Kerala (India). South Asian Journal of Tourism and Heritage, 1(1), 57-64.

Liu, A. (2006). Tourism in rural areas: Kedah, Malaysia. Tourism Management, 27, 878-889. http://dx.doi.org/10.1016/j.tourman.2005.05.007

MacDonald, R., \& Jolliffe, L. (2002). Cultural Rural Tourism: Evidence from Canada. Annals of Tourism Research, 30(2), 307-322. http://dx.doi.org/10.1016/S0160-7383(02)00061-0

Nepal, S. K. (2007). Tourism and Rural Settlements Nepal's Annapurna Region. Annals of Tourism Research, 34(4), 855-875. http://dx.doi.org/10.1016/j.annals.2007.03.012

Panyik, E., Costa, C., \& Rátz, T. (2011). Implementing integrated rural tourism: An event-based approach. Tourism Management, xxx, 1-12.

Park, D. B., \& Yoon, Y. S. (2009). Segmentation by motivation in rural tourism: A Korean case study. Tourism Management, 30, 99-108. http://dx.doi.org/10.1016/j.tourman.2008.03.011

Perales, R. M. Y. (2002). Rural Tourism in Spain. Annals of Tourism Research, 29(4), 1101-1110. http://dx.doi.org/10.1016/S0160-7383(02)00025-7

Rathod, H., \& Rathod, B. (2009). Poharadevi - A study in pilgrimage tourism center in Maharashtra. International Research Journal, II(5), 530-532.

Rotherham, I. D. (2007). Sustaining Tourism Infrastructures for Religious Tourists and Pilgrims within the UK. Tourism Leisure and Environmental Change Research Unit, Sheffield Hallam University, Sheffield, UK, 64-77.

Saxena, G., \& Ilbery, B. (2007). Integrated rural tourism: A Border Case Study. Annals of Tourism Research, 35(1), 233-254. http://dx.doi.org/10.1016/j.annals.2007.07.010

Saxena, G., \& Ilbery, B. (2010). Developing integrated rural tourism: Actor practices in the English/Welsh border. Journal of Rural Studies, 26, 260-271. http://dx.doi.org/10.1016/j.jrurstud.2009.12.001

Sharpley, R. (2002). Rural tourism and the challenge of tourism diversification: the case of Cyprus. Tourism Management, 23, 233-244. http://dx.doi.org/10.1016/S0261-5177(01)00078-4

Sharpley, R., \& Jepson, D. (2010). Rural Tourism: A spiritual experience? Annals of Tourism Research, 38(1), 52-71. http://dx.doi.org/10.1016/j.annals.2010.05.002

$\mathrm{Su}$, B. (2011). Rural tourism in China. Tourism Management, $x x x, 1-4$.

UNWTO. (2011). Religious Tourism in Asia and the Pacific. World Tourism Organization, Madrid, Spain, $1-367$. 